\title{
Surgical Ovary Masses in Children: A Single Center Experience of 11 Years
}

\author{
Çocuklarda Cerrahi Over Kitleleri: 11 Yıllık Deneyim
}

\author{
Zeliha AKIS YILDIZ', Mehmet ARPACIK' ${ }^{1}$, Begum KOC², IIlkay TOSUN ${ }^{3}$, Cem YALCINKAYA4, \\ Zekeriya ILCE ${ }^{1}$
}

'University of Health Sciences, İstanbul Ümraniye Training and Research Hospital, Pediatric Surgery Clinic, İstanbul, Turkey ${ }^{2}$ University of Health Sciences, İstanbul Ümraniye Training and Research hospital, Hematology Oncology Clinic, İstanbul, Turkey ${ }^{3}$ University of Health Sciences, İstanbul Ümraniye Training and Research Hospital, Pathology Clinic, İstanbul, Turkey

${ }^{4}$ University of Health Sciences, İstanbul Ümraniye Training and Research Hospital, Gynecology and Obstetrics Clinic, İstanbul, Turkey

\begin{abstract}
Objective: The majority of childhood ovarian masses are benign. However, malignant tumors encountered in adulthood may also be seen in childhood. There is still no ovarian tumor management protocol for children. We shared our experiences with ovarian mass cases operated in our clinic.
\end{abstract}

Material and Methods: Patients aged 0-18 years and had surgery in our hospital between 2010 and 2020 due to ovarian masses were included in the study. The ages of the patients, the maximum diameter and structure of the mass on ultrasonography (USG) and other imaging modalities, symptoms on presentation, tumor markers, operation data, and histopathology results were recorded. The patients were divided into three groups in relation with tumor histopathology, and the demographic data were compared among groups.

Results: In 11 -year period, 107 surgical operations were performed on 106 patients due to ovarian masses. The ages of the patients were between 2 days and 17 years, with a mean age of $13.4 \pm 14.1$ years. Of the masses, $9(8.4 \%)$ were malignant (3 (2.8\%) borderline), 44 (41.1\%) were benign, and 54 (50.5) were non-neoplastic. Histopathology results of 53 surgical operations performed for neoplastic ovarian masses were germ cell tumor in 31 (29\%), epithelial tumor in 19 (17.8\%), sex cord stromal tumor in 2 (1.9\%), and leiomyoma 1 (0.9\%) patient.

Conclusion: Adult protocols should be used when necessary in rare childhood ovarian malignant tumors, and large multicenter patient series should be constituted in order to establish pediatric protocols related to the subject. A multidisciplinary approach is necessary in childhood ovarian masses.

Key Words: Children, Masses, Ovary, Surgery

\section{ÖZ}

Amaç: Çocukluk çağı over kitlelerinin çoğunluğu benigndir. Ancak yetişkinlik döneminde görülen malign tümörlerde çocukluk çağında görülebilmektedir. Bu tümörlerel ilgili çocukluk çağına ait bir protokol hala yoktur. Bizde kliniğimizde opere edilen over kitleleri ile ilgi deneyimimizi paylaştık.

(1)

0000-0001-7637-6512:AKIS YILDIZZ 0000-0001-7149-5627:ARPACIK M 0000-0002-6127-3147:KOC B 0000-0001-6655-1014:TOSUN I 0000-0001-7533-0838:YALCINKAYA C 0000-0002-3473-5051:ILCE Z
Conflict of Interest / Çıkar Çatışması: On behalf of all authors, the corresponding author states that there is no conflict of interest.

Ethics Committee Approval / Etik Kurul Onayı: This study was conducted in accordance with the Helsinki Declaration Principles. Ethical approval for this study was obtained from the ethics committee of Umraniye Training and Research Hospital (29.04.202-139).

Contribution of the Authors / Yazarların katkıSI: AKIS YILDIZ Z: Planning methodology to reach the Conclusions, Taking responsibility in patient follow-up, collection of relevant biological materials, data management and reporting, execution of the experiments, Taking responsibility in logical interpretation and conclusion of the results, Taking responsibility in necessary literature review for the study, Taking responsibility in the writing of the whole or important parts of the study. ARPACIK M: Taking responsibility in patient follow-up, collection of relevant biological materials, data management and reporting, execution of the experiments, aking ARPACIK M: Taking responsibility in patient follow-up, collection of relevant biological materials, data management and reporting, execution of the experiments, aking
responsibility in necessary literature review for the study, Taking responsibility in the writing of the whole or important parts of the study, Reviewing the article before submission scientifically besides spelling and grammar. KOC B: Organizing, supervising the course of progress and taking the responsibility of the research/study, Taking responsibility in patient follow-up, collection of relevant biological materials, data management and reporting, execution of the experiments, Taking responsibility in the writing of the whole or important parts of the study. TOSUN I: Planning methodology to reach the Conclusions, Taking responsibility in logical interpretation and conclusion of the results, Taking responsibility in necessary literature review for the study, Reviewing the article before submission scientifically besides spelling and grammar. YALCINKAYA C: Organizing, supervising the course of progress and taking the responsibility of the research/study, Taking responsibility in patient followup, colloction of revant biological meterials, deta managent and reporting, execution of the experiments, Reviewing the article before submission scientifically up, coction ( biological materials, data management and reporting, execution of the experiments, Taking responsibility in logical interpretation and conclusion of the results, Taking responsibility in necessary literature review for the study, Reviewing the article before submission scientifically besides spelling and grammar.

How to cite / Atıf yazım şekli : Akis Yildiz Z, Arpacik M, Koc B, Tosun I, Yalcinkaya C and llce Z. Surgical Ovary Masses in Children: A Single Center Experience of 11 Years. Turkish J Pediatr Dis 2022;16:318-325.
Correspondence Address / Yazışma Adresi:

University of health sciences İstanbul Ümraniye Training and Research hospital,

Pediatric Surgery Clinic, İstanbul, Turkey

E-posta: zelihaakis@gmail.com
Received / Geliş tarihi : 01.10.2021 Accepted / Kabul tarihi : 15.11.2021 Online published Elektronik yayın tarihi

DOI: 10.12956/tchd.1002678 
Gereç ve Yöntemler: Hastanemizde 2010 ile 2020 yılları arasında over kitlesi nedeniyle opere edilen 0 ila 18 yaş arası olgular çalışmaya dahil edildi. Hastaların yașları, ultrasonografi (USG) ve diğer yapılan görüntüleme yöntemlerinde kitlenin maksimum çapı ve yapısı, başvuru semptomları, tümör belirteçleri, operasyon verileri, patoloji sonuçları kaydedildi. Patolojiye göre 3 gruba ayrılarak demografik veriler karşılaştırıldı.

Bulgular: Çalışmanın yapıldığı 11 yıllık süreçte 106 olguya over kitlesi nedeniyle 107 ameliyat yapılmıştır. Olguların yaşları 2 gün ile 17 yaş arasında değişmekle birlikte ortalaması 13.4 14.1'dir. Bu ameliyatlardan 9 (\%8.4)'ü malign (3'ü (\%2.8) borderline), ve 44 (\%41.1)'i benign neoplastik over kitlesi, 54 (50.5)'i nonneoplastik over kitlesiydi. Neoplastik over kitlesi nedeniyle yapılan 53 ameliyatta patoloji sonuçları; olgulardan 31 (\%29)'u germ hücreli tümör, 19 (\%17.8)'i epitelyal tümörler, 2 (\%1.9)'u seks kord stromal tümör, 1 (\%0.9) leomiyom olarak değerlendirildi.

Sonuç: Çocukluk çağı over kitlelerinde multidisipliner yaklaşım unutulmamalıdır. Çocukluk çağında az görülen over tümörlerinde gerektiğinde yetişkin protokollerinden yararlanılırken, çok merkezli çalışmalarla seriler oluşturulmalı ve böylece konu ile ilgili çocuk protokolleri oluşturulmalıdır.

Anahtar Sözcükler: Çocuk, Kitleler, Over, Cerrahi

\section{INTRODUCTION}

The majority of childhood ovarian masses are benign. The most common ovarian masses are non-neoplastic ones such as simple cysts and torsions $(1,2)$. Neoplastic ovarian masses originate from germ, stromal and epithelial cells. In childhood, most common tumors are germ cell tumors, and comprise 60$85 \%$ of all tumors. Epithelial neoplasms are encountered most frequently in adults, on the contrary, these are quite rare in children $(3,4)$.

Although the exact rate of malignancy in the childhood is not known, the risk for a malignant ovarian mass is at least 100 times lower than in postmenopausal women $(3,5)$. Adult ovarian malignancy treatment protocols are clear since ovarian malignancies are frequent in adulthood. However, only case reports and small series have been published concerning childhood ovarian masses, and treatment protocols are not as straightforward as adults.

Although the risk of malignancy is low in childhood ovarian masses, the rate of oophorectomy is high in benign masses. This is mostly due to the fear of malignancy and supposing that the torsioned ovary will not function due to necrosis. Performing oophorectomy in the children increases the risk of both future infertility and the risk of premature menopause. While aiming to protect patients from malignancy, new problems are created by performing oophorectomy in harmless benign masses (5-7).

In our study, demographic, clinical and histopathological characteristics of pediatric cases who had surgery for ovarian masses in Umraniye Training and Research Hospital, a tertiary pediatric hospital with pediatric surgery and gynecology clinics, will be presented, and childhood ovarian malignancies will be discussed in the light of the literature.

\section{MATERIAL and METHODS}

The patients between 0 and 18 years of age and diagnosed with an ovarian mass in Umraniye Training and Research Hospital between 2010 and 2020 were retrospectively analyzed using the hospital registry system. Ethical approval for this study was obtained from the ethics committee of Umraniye Training and Research Hospital (29.04.202-139).

The patients who underwent surgical procedures were included in the study. Cases with incomplete medical records, masses other than ovarian masses, surgical procedures performed for sexual development disorders, and the cases that did not have surgery were excluded. The ages of the patients, the maximum diameter and structure of the mass on ultrasonography (USG) and other imaging modalities, symptoms on presentation, tumor markers, operation data, and histopathology results were recorded.

The type of the surgical procedure was recorded as open surgery or laparoscopic surgery. The surgical procedures were grouped as oophorectomy/salpingo-oophorectomy, ovarysparing surgery and only detorsion. Masses were first divided into two groups as non-neoplastic and neoplastic. Neoplastic masses were again divided into two groups as benign and malignant masses.

In the non-neoplastic group, simple cysts were grouped as hemorrhagic cysts, necrosis due to torsion, and the cases that had surgery for torsion only and detorsioned. Tumors were divided into four main groups as neoplastic germ cell tumors, sex-cord stromal tumors, epithelial tumors and the others. Malignant neoplastic masses and the tumors with low malignancy potential (borderline) were included in the malignant masses group. The cases were divided into three groups in terms of ages, as 0-9, 10-13, and 14-17 year-old groups.

The data were analyzed with IBM SPSS statistics 22 program (IBM SPSS, Turkey). Descriptive statistics were employed to analyze frequency distribution and the means. The $x 2$ (Chisquare) and Fisher's exact tests were used to compare two groups. Significance level was set at $p<0.05$.

\section{RESULTS}

A total of 371 patients were diagnosed with ovarian masses in an 11-year period. Of these, 265 patients were followed up 
Table I: Childhood ovarian masses that had surgery.

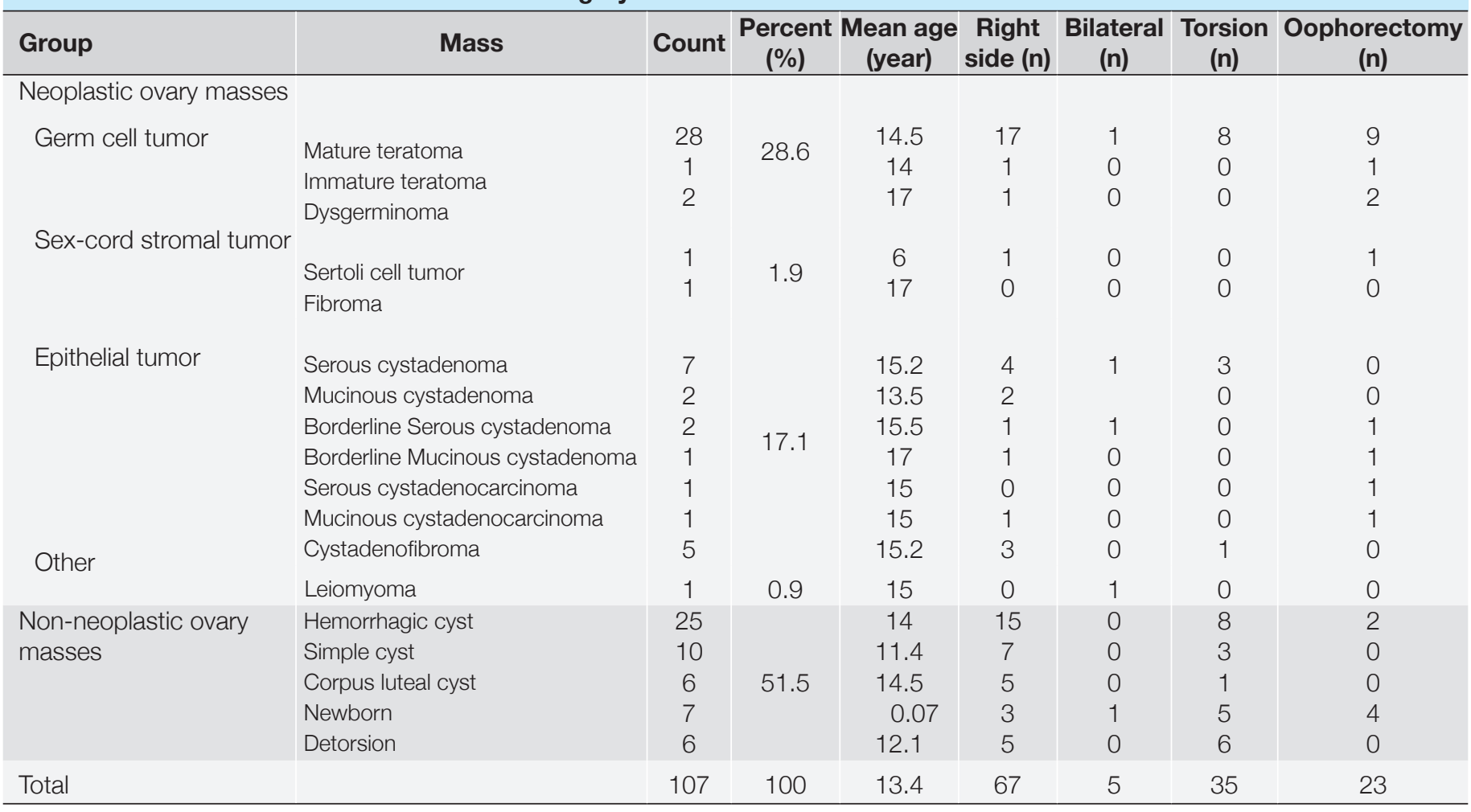

without surgery, and 107 surgeries were performed on 106 patients. Of these masses, 9 (8.4\%) were malignant (3 (2.8\%) borderline), and 44 (41.1\%) were benign neoplastic ovarian masses while 54 (50.5) were non-neoplastic ovarian masses. The histopathology result was not available in 6 (5.6\%) cases who had only detorsion. The histopathology results of 53 surgical operations performed for neoplastic ovarian mass were: germ cell tumor in 31 (29\%), epithelial tumors in 19 $(17.8 \%)$, sex cord stromal tumor in $2(1.9 \%)$, and leiomyoma in 1 (0.9\%) patient (Table I).

The ages of the patients were between 2 days and 17 years with a mean age of $13.4 \pm 14.1$ years. The patients under one year of age constituted $6.6 \%$ of all cases. There were 12 (11.3\%) cases in the 0-9 year-old group, $26(24.5 \%)$ cases in the 10 13 year-old group, and 69 (65\%) cases in the 14-17 year-old group. The age groups were compared in terms of ovarian mass histopathology (Figure 1). As the patient's age increased, the number of patients with an ovarian mass also increased. The prevalence of malignant ovarian masses was significantly higher in patients aged 14 years and over $(p<0.006)$.

The surgical technique was laparotomy in 61 patients, laparoscopy in 45 patients and drainage in 1 patient. It was seen that the laparoscopy rate has increased significantly after 2015 ( $p<0.008$ ). Unilateral oophorectomy or unilateral salpingo-oophorectomy was performed in 21 (19.6\%), bilateral salpingo- oophorectomy in 2 (1.8\%), ovary conserving surgery in $78(72.8 \%)$, and only detorsion in $6(5.6 \%)$ of the surgical operations. Among 9 patients with malignant or borderline histopathology, 8 (88.8\%) had unilateral oophorectomy or salpingo-oophorectomy, 1 had bilateral salpingo-oophorectomy, and only mass excision was performed in a borderline case. Oophorectomy or salpingo-oophorectomy was performed in $15(15.3 \%)$ of 98 non-malignant cases. Of these cases, 4 (4.08\%) had necrosis due to torsion in the neonatal period, 8 (8.11\%) had masses with torsion and had emergency surgical operations, and $3(3 \%)$ had solid ovarian masses that could not be dissected from the normal ovarian tissue.

The presenting complaint was abdominal pain in 75 (70.1\%) patients, 7 (6.5\%) patients had problems related to menstruation, 12 (11.2\%) patients had complaints other than abdominal pain and menstruation problems (abdominal distension, nausea, vomiting, groin pain), 1 (0.9\%) patient who previously had surgery for borderline serous cystadenoma had surgery due to a mass appeared in her follow-up, and in 12 $(11.2 \%)$ cases the ovarian masses were diagnosed incidentally (Figure 2). While $73(74.48 \%)$ of 98 benign cases presented with abdominal pain, this rate was $2 / 9(22.22 \%)$ in malignant cases (including borderlines). Cases with benign masses presented with abdominal pain more frequently compared to the malignant cases, the difference being statistically significant $(p<0.001)$.

The mass was located in the right ovary in $66(62.2 \%)$, in the left ovary in 35 (33\%), and bilateral ovaries in 5 (4.7\%) patients. There was no statistically significant difference between the 


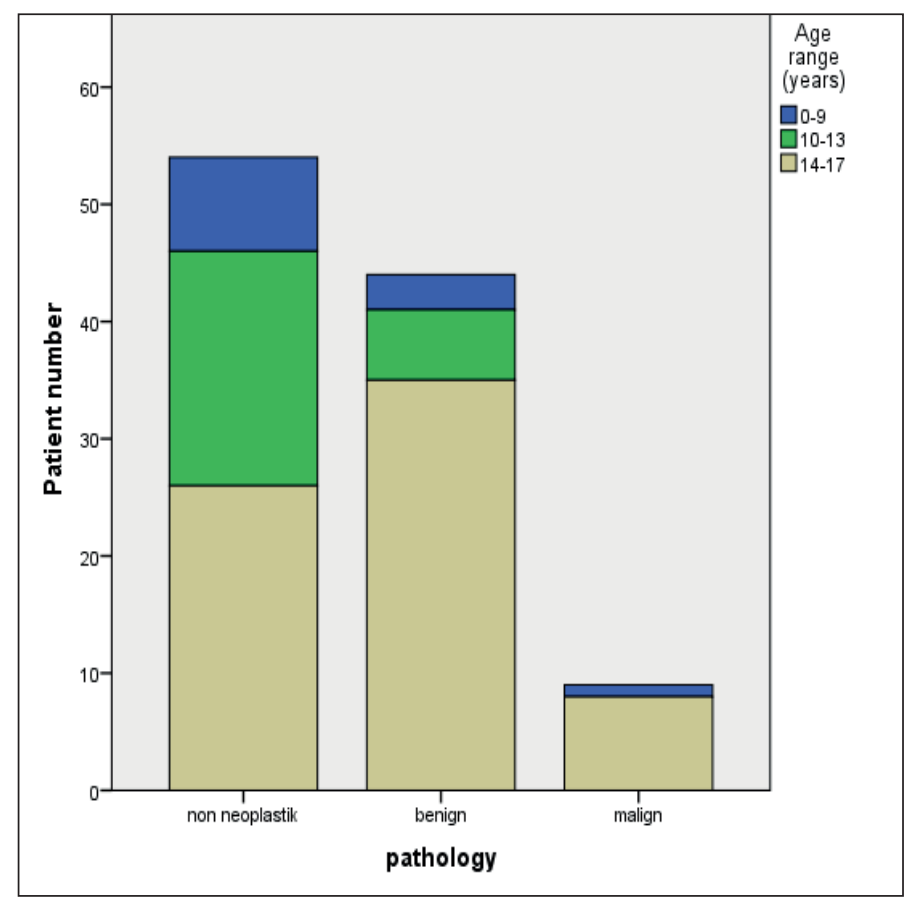

Figure 1: Age distribution in relation with ovarian mass histopathology.

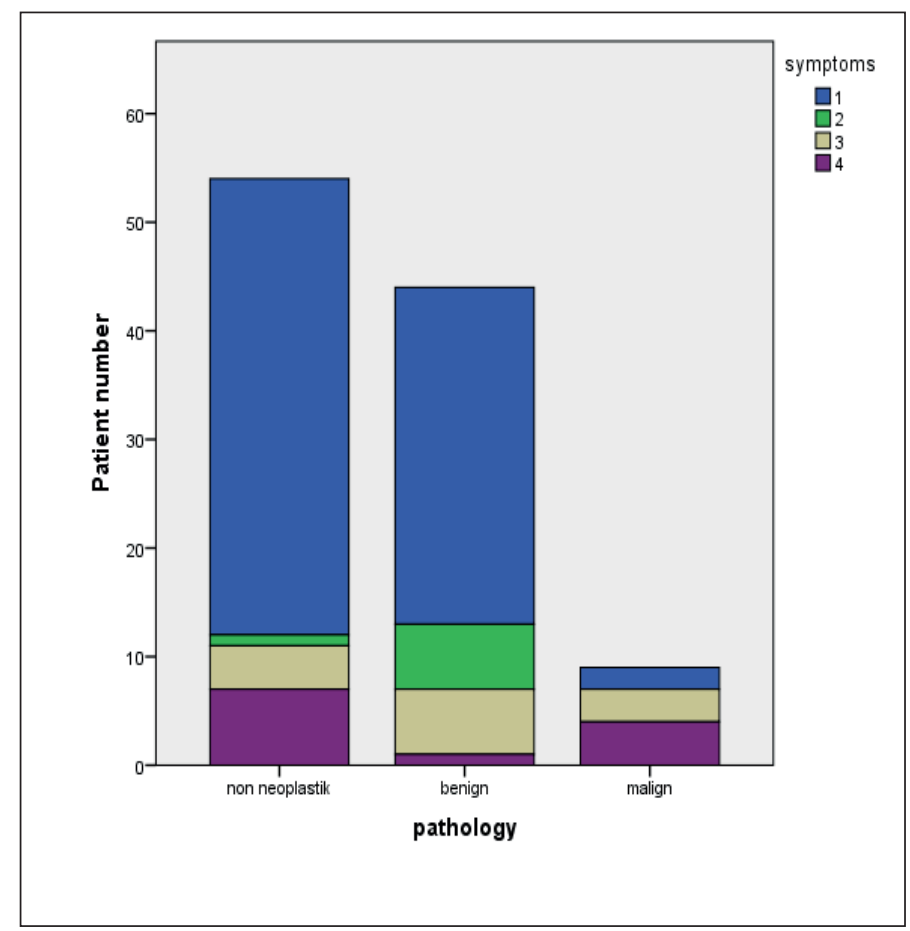

Figure 2: Distribution of the presentation symptoms in relation with the histopathology of the masses (1-abdominal pain, 2-menstrual problems, 3-other 4-incidental).

masses with or without torsion for their localization in right or left ovaries $(p<0.816)$. Likewise, there was no statistically significant difference in the right or left ovarian localization of malignant, benign or non-neoplastic masses ( $p<0.475)$.

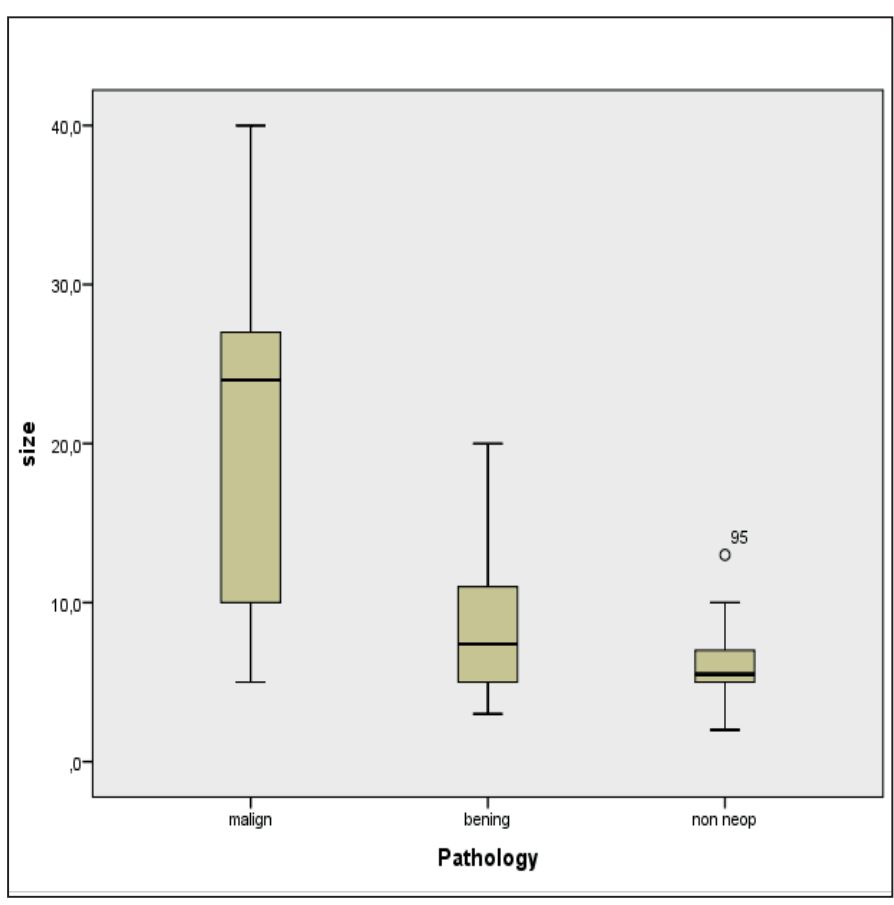

Figure 3: Distribution of the greatest diameter of ovarian masses in relation with their histopathology.

Preoperative USG was not performed in only 4 cases. In these cases, ovarian cysts were detected incidentally during appendectomy, and cystectomy was performed. On USG, a solid component or complex structure was detected in 40 cases, 10 cases were reported as torsion only, 25 cases were reported as masses with torsion, and 28 cases were reported as simple or hemorrhagic cysts. Nine (25.7\%) of the 35 cases considered to have torsion on USG were not evaluated as torsion at surgery. Twenty-four of 32 cases found to have torsion during surgery were also reported as torsion on USG, but 3 of the other 8 (25\%) cases were evaluated as solid mass, and 5 as simple cysts. Oophorectomy was performed in 13 $(40.6 \%)$ of 32 cases with torsion. None of the cases with a malignant or borderline histopathology had torsion.

The largest mean diameter of the mass was found as 20.66 $\mathrm{cm}$ in malignant and borderline masses, and $7.35 \mathrm{~cm}$ in benign masses (Figure 3). The diameters of malignant masses were statistically significantly greater than benign masses $(p<0.001)$.

Preoperative tumor markers were requested in all cases with neoplastic masses. In non-neoplastic masses, tumor markers were not requested in 18 of 54 patients. At least one of cancer antigen 125 (CA125), beta-human chorionic gonodotropin (BHCG), alpha fetoprotein (AFP), lactate dehydrogenase (LDH), carcinoembryonic antigen (CEA) was high in 22 (24.7\%) of 89 cases for whom tumor markers were requested. High levels were found in $7(77.7 \%)$ malignant, $10(22.7 \%)$ benign, and 5 (13.8\%) non-neoplastic ovarian masses. Tumor markers were significantly higher in malignant masses $(p<0.001)$. Seventy- 
eight $(72.89 \%)$ cases were operated by pediatric surgeons and $29(27.10 \%)$ cases by gynecologists. The cases operated by gynecology and pediatric surgery were compared for their ages: younger or older than 14 years of age. The gynecology department statistically significantly operated more cases over the age of 14 years $(p<0.001)$.

\section{DISCUSSION}

In our hospital, which is a tertiary health center, 78 out of 107 pediatric ovarian masses were operated by pediatric surgery in 11 years, and this corresponds to 7 cases/year. Considering that an average of 2000 children have surgery annually in our clinic, we may say that pediatric surgeons rarely perform surgery on ovarian masses when compared to other surgical operations. In our institution, 1/3 of the total childhood ovarian pathologies were operated by gynecologists. A number of studies in the literature on childhood ovarian masses were published by gynecologists. In particular, ovarian masses of adolescents are treated by gynecologists in many institutions $(2,3,7,8)$. Although pediatric surgeons did not work regularly and actively in our institution between whiles in the 11-year period included in our study, surgical operations of most of the cases were performed by pediatric surgeons.

Publications often include limited number of cases due to the rarity of childhood ovarian masses. These publications mostly included patients over 18 years of age $(1,3,8,9)$. However, the international Committee on the Rights of the Child defines the child as an individual under the age of 18 years (10). In our study, the characteristics of ovarian disorders needing surgery were investigated including only the patients under the age of 18 into the study.

The mean age of our patients was $13.4 \pm 14.1$ years. Although the patients aged 18 and over were not included in our study, the mean age of our patients was greater than in most of the previous studies $(1,7,8,11)$. The mean ages in the investigations performed in obstetrics and gynecology departments are greater than in our study, on the other hand, the mean ages are smaller in studies conducted in pediatric surgery departments $(1,2,7-9,11)$. This may be due to the fact that gynecologists mostly perform surgery on adolescents, and pediatric surgeons operate infants and younger patients. Our results indicated that the gynecologists performed surgery on adolescents at a statistically significantly higher rate in our hospital. Another reason may be that we do not remove simple ovarian cysts in neonates since the risk of malignancy is very small in patients under 1 year of age $(1,3)$. In our study, we did not encounter any malignant ovarian tumors in patients younger than 1 year of age.
Compared to other studies, the prevalence of malignant ovarian masses in patients $\geq 14$ years is higher in our study. This is probably due to the fact that germ cell malignancies and sex cord stromal tumors seen in younger ages are less in number in our series compared to other studies, and epithelial tumors are more $(1,2,9,11)$.

Similar to previous studies, most of the ovarian pathologies in our study were located in the right ovary. It has been argued that the reason for this is that the ovarian masses on the right side had surgery considering acute appendicitis, while those on the left ovary were usually left undiagnosed. In addition, it has been claimed that the left ovary is protected from torsion due to presence of the sigmoid colon, and therefore ovarian torsions mostly occur in the right ovary $(5,8,12,13)$. However, in our study, either histopathology of the mass or the presence of torsion were not significantly correlated with the side of the ovarian mass.

The most frequent presenting symptom of the patients is abdominal pain. Similar to other studies, $71 \%$ of the patients in our study presented with abdominal pain $(2,3)$. In our study, the patients with non-neoplastic or benign masses mostly presented with abdominal pain, while the patients with malignant masses presented with symptoms such as abdominal distension, or were diagnosed incidentally.

Although USG is not as reliable and sensitive in children as in adults, it is the preferred imaging modality for ovarian masses in our clinic, as in other clinics (1). Magnetic resonance (MRI) or Computed Tomography (CT) is requested if the mass contains a solid component, suspicion of malignancy or if torsion cannot be distinguished on USG. MRI or CT imaging was available in addition to USG in all of our patients who had surgery due to malignancy. It has been shown in a number of studies that the risk of malignancy increases as the diameter of the mass increases on USG. It has been widely agreed that the risk for malignancy is higher in large masses $(8,11,13)$. In our study, malignant masses had significantly bigger diameters compared to benign masses.

We request tumor markers in our clinic if there is a neoplastic appearance on USG (presence of a solid component, complicated cyst) or if the diameter of the mass is $\geq 5 \mathrm{~cm}$. However, tumor markers are less specific in the childhood age compared to the adults (1). Tumor markers were high in only $24.7 \%$ of our cases. Hembram et al.(8) found high tumor marker levels in $12 \%$ of 58 ovarian masses that had surgery, however their sample size was smaller than our study. In a study conducted in China, high tumor marker levels were found in $73 \%$ of the malignant ovarian masses and in $20 \%$ of the nontumorous masses (2). Similarly, in our study, high tumor marker levels were found in $77.7 \%$ of the malignant masses and in $13.8 \%$ of the non-neoplastic masses. 
In a meta-analysis covering 44 publications on childhood ovarian masses between 2000 and 2017, 24 publications analyzed laparoscopy. Malignant masses were included in only one of those publications. In that study, only 2 cases with malignant masses had laparoscopic surgery. Time of surgery, amount of bleeding and hospital stay were found to be lower in laparoscopic surgery. However, there are no sufficient data regarding tumor rupture and spillage into the abdomen when malignant masses are operated laparoscopically (14). In our study, only 1 case with a malignant mass had laparoscopic surgery. There was no tumor rupture or spillage during surgery. Although we wanted to prefer laparoscopic surgery in other malignant masses encountered after 2015 , open surgery was preferred due to the fact that the masses were over $30 \mathrm{~cm}$ in diameter, they did not leave enough working space in the abdomen, and a large incision would be needed to remove the mass without rupturing it (Figure 1). Other studies have also reported that laparoscopy can be performed safely for benign masses, however open surgery is recommended for malignant masses (1.8).

In publications on adult ovarian masses, it has been argued that laparoscopy could be safely performed in malignant masses (15). In our clinic, the malignancy rate is $8.4 \%$, while the rate of laparoscopy is $42.1 \%$. Although the laparoscopy rate is low in our clinic, the significant increase in this rate after 2015 shows that our experience both with laparoscopy and ovarian masses has increased over time. In previous studies, the rate of laparoscopy has also increased over time $(1,3)$.

Approximately $9-30 \%$ of ovarian pathologies present with torsion $(6,7,9,12)$. In our study, this rate is $32 \%$, and higher than in other studies. The treatment of torsioned ovary has changed over time from oophorectomy to ovary sparing surgery. Today, oophorectomy is not recommended even if the ovary is necrotic $(16,17)$. A study conducted in the USA in 2015 reported oophorrectomy rate as 78\% on 2041 pediatric ovarian torsion cases (16). Similarly, another study from USA in 2020 reported oophorectomy rate as $22.5 \%$. Recently, it has been argued that the rate of oophorectomy has been decreasing in cases with torsion, but this is still not sufficient (17). In our clinic, the rate of oophorectomy in cases with torsion is at an acceptable level with $40.6 \%$, according to these studies. In our clinic, oophorectomy was performed in 4 cases with intrauterine torsion in order to protect the patient from infection with necrotic ovarian tissue, resembling a parchment paper. Apart from this, oophorectomy has been performed mostly in torsioned mature cystic teratomas. Perhaps, the fact that malignancy risk cannot be excluded since a frozen section is not available in cases with ovarian torsion and a solid mass who had surgery at night, and impossibility to dissect the ovary with impaired circulation from the mass, lead us, pediatric surgeons, to oophorectomy. Although the risk of malignancy in a torsioned ovary in childhood is not known exactly, it was found as $1.8 \%$ in a study by Oltmann et al. (18). Apart from this, as in our study, malignancy was not found in torsioned ovary pathologies in a number of studies. These show that worrying for malignancy is unfounded. Lately, it has been recommended that the mass or malignancy should be evaluated with postoperative USG after detorsion if it is not possible to dissect the ovarian tissue from the mass during surgery in cases with a mass and torsioned ovary (16-18).

The rate of oophorectomy in operated ovarian masses varies between $18 \%$ and $35 \%$ when torsion cases are not analyzed separately in studies $(2,3,5,8,9)$. Oophorectomy or salpingooophorectomy was performed in $23(21.4 \%)$ of our cases. This rate is similar to the rates in other studies. However, since we performed only 9 operations for malignancy, this indicates that we performed oophorectomy due to the suspicion of malignancy in benign masses or due to ovarian torsion. Although fertility is preserved in unilateral oophorectomy, this surgery is not harmless. Some studies have reported cognitive impairment and predisposition to Parkinson's disease after unilateral oophorectomy (11). Studies have shown that the rate of ovary sparing surgery is gradually increasing (5).

Ovarian tumors constitute $1 \%$ of all tumors in the childhood. The probability of malignancy is between $4 \%$ and $20 \%$ in patients that had surgery due to ovarian masses (5). In our study, 5.6\% of the cases had malignant and $2.8 \%$ of them had borderline tumors. Similar to our study, the most common tumors in other studies were germ cell tumors and epithelial tumors in rank order, while sex cord stromal tumors were the least frequently encountered tumors $(1,2,14)$. Although germ cell neoplasms are the most frequently encountered tumors in those studies, their risk of malignancy is lower than the epithelial tumors. The possibility of malignancy is higher in epithelial tumors compared to germ cell tumors especially when borderline and malignant tumors are taken together. In our study, the rate of malignancy is not low in epithelial tumors, and has been found as 4/18 (22.22\%). However, it has been claimed that epithelial tumors constitute only $2-5 \%$ of malignant ovarian masses in childhood, and they are quite rare in children $(19,20)$. When our cases are analyzed in terms of malignant masses, 4/8 (50\%) of our cases had epithelial malignant tumors when 2/6 (33\%) borderline masses were included.

Childhood epithelial ovarian cancer is more common at the ages of 15-19 years. Data are very limited on childhood ovarian cancers. That is why adult data are used. In children, mucinous ovarian carcinoma or low-grade serous ovarian carcinoma are seen most frequently, and their prognosis is better than in the adults (21). Treatment should include oophorectomy, removal of tumor-bearing tissues, and staging. Fertility preserving surgery is recommended, but conservative treatment should be avoided in bilateral stage 1, stage 2, and stage 3 cases, and bilateral salpingo-oophorectomy and hysterectomy should be performed $(1,15,22)$. Although fertility sparing surgery is preferred in stage 1 cases, surgical treatment should be 
completed by performing unilateral salpingo-oophorectomy and hysterectomy after the reproduction period (23).

We performed unilateral salpingo-oophorectomy in 2 cases followed up due to mucinous cystadenocarcinoma and borderline epithelial tumor, and ovary-sparing surgery was performed in a borderline case. However, our case with serous borderline tumor in which we performed unilateral oophorectomy had recurrence, and diagnosed with serous adenocarcinoma. In this case, oophorectomy of the contralateral ovary and hysterectomy were performed.

A council attended by pediatric surgery, obstetrics, and oncology departments was held for all patients with epithelial malignancies to decide their treatments.

Frozen section should be performed in case of a suspicion for malignancy in ovarian masses. If frozen section indicates an epithelial ovarian cancer; abdominal washing, biopsies of peritoneum and omentum, and intraoperative abdominal exploration should be performed. If frozen section is not available, all those mentioned above should be performed in any case $(15,24)$. We performed frozen section and intraoperative abdominal exploration in all of our malignant cases.

Recurrence is seen in one of three cases with epithelial borderline tumors after fertility-sparing surgery. These cases must be followed up with CA125 levels and radiological imaging. The risks of osteoporosis, and cardiovascular and neurological disorders increase after bilateral salpingo-oophorectomy and hysterectomy in malignant tumors. The patients should be followed up for those disorders. It is very difficult to overcome these complications in children compared to postmenopausal women who have completed their fertility. It is oncologically safe to keep the contralateral ovary and uterus only in unilateral stage 1 cases to prevent these complications, and to ensure fertility. In low-grade carcinomas, patients may also benefit from postoperative chemotherapy. Carboplatin and paclitaxel are mostly recommended in these cases. Although $90 \%$ of epithelial ovarian cancers are sporadic, $10 \%$ are due to genetic mutations. Genetic consultation should be performed in cases with childhood epithelial ovarian cancers $(15,24)$.

The present study has a number of limitations. First, in a retrospective single-center review of medical records, some details of history and physical examinations may not be rigorously documented. Second, small sample size and the exclusion of ovarian masses that were not operated. These limitations may have led to bias in analyzing the clinical spectrum of ovarian masses in children.

\section{CONCLUSION}

When faced with an ovarian mass, it should be remembered that a multidisciplinary approach is needed. Except for cases requiring emergency surgery such as torsion, all necessary examinations and radiological imaging should be performed, and the opinions of the relevant departments should be obtained. We should increase the rate of laparoscopic surgery and ovary conserving surgery, which positively affect the quality of life of patients, and avoid oophorectomy, particularly in ovarian torsion. Adult protocols should be used when necessary for rare childhood ovarian tumors, such as epithelial tumors, and large multi-center patient series should be constituted in order to establish pediatric protocols related to the subject.

\section{REFERNSES}

1. How JA, Marino JL, Grover SR, Heloury Y, Sullivan M, Mellor A, et al. Surgically Managed Ovarian Masses at the Royal Children's Hospital, Melbourne -19 Year Experience. J Pediatr Surg 2019;54:1913-20.

2. Liu H, Wang X, Lu D, Liu Z, Shi G. Ovarian masses in children and adolescents in China: analysis of 203 cases. J Ovarian Res 2013;6:47. doi: 10.1186/1757-2215-6-47. eCollection 2013.

3. Kirkham YA, Lacy JA, Kives S, Allen L. Characteristics and Management of Adnexal Masses in a Canadian Pediatric and Adolescent Population. J Obstet Gynaecol Can 2011;33:935-43.

4. Grapsa D, Kairi-Vassilatou E, Kleanthis C, Dastamani C, Fillipidou A, Kondi-Pafiti A. Epithelial Ovarian Tumors in Adolescents: A Retrospective Pathologic Study and a Critical Review of the Literature. J Pediatr Adolesc Gynecol 2011;24:386-8.

5. Xac MC, Jetelina KK, Jarin J, Wilson E. Benign, Borderline, and Malignant Pediatric Adnexal Masses: A 10-Year Review. J Pediatr Adolesc Gynecol 2021;34:454-61.

6. Wong YS, Tam YH, Pang KK, Mou JW, Chan KW, Lee KH. Oophorectomy in children. Who and why: 13-year experience in a single centre. J Paediatr Child Health 2012;48:600-3.

7. Hermans AJ, Kluivers KB, Wijnen MH, Bulten J, Massuger LF, Coppus SF. Diagnosis and treatment of adnexal masses in children and adolescents. Obstet Gynecol 2015;125:611-5.

8. Hembram M, Sagili H, Dasari P. A retrospective analysis of surgically managed adnexal masses in children and adolescents in a tertiary centre. Front Womens Healt, 2016;1:52-4 .

9. Cass DL, Hawkins E, Brandt ML, Chintagumpala M, Bloss RS, Milewicz AL, et al. Surgery for ovarian masses in infants, children, and adolescents: 102 consecutive patients treated in a 15-year period. J Pediatr Surg 2001;36:693-9.

10. "Article 1 of the Convention on the Rights of the Child". Website of the Office of the United Nations High Commissioner for Human Rights (OHCHR). United Nations. 20 November 1989. http://www.ohchr.org/en/professionalinterest/pages/crc.aspx. (accessed 13 April 2021).

11. Nasioudis D, Alevizakos M, Holcomb K, Witkin SS. Malignant and borderline epithelial ovarian tumors in the pediatric and adolescent population. Maturitas 2017;96:45-50.

12. Sadeghian N, Sadeghian I, Mirshemirani A, Tabari AK, Ghoroubi J, Gorji FA, et al. Types and frequency of ovarian masses in children over a 10-year period. Caspian J Intern Med 2015;6:220-3.

13. User IR, Karakuş SC, Özokutan BH, Akçaer V, Burulday B, Ceylana $\mathrm{H}$. Can preoperative findings help to interpret neoplastic and non-neoplastic lesions of ovary and affect surgical decisions 
in children and adolescents?. Arch Argent Pediatr 2019;117:294400.

14. Qazi SH, Jeelani SM, Dogar SA, Das J, Saxena AK. Approaches to the management of pdiatric ovaian masses in 21st century: Systematic review and meta-analysis. J Pediatr Surg 2020;55:35768.

15. Coleman RL, Ramirez PT, Gershenson DM. Neoplastic diseases of the ovary: screening, benign and malignant epithelial and germ cell neoplasms, sex-cord stromal tumors. In: Lobo RA, Gershenson DM, Lentz GM, Valea FA, eds. Comprehensive Gynecology. $7^{\text {th }}$ ed. Philadelphia, PA: Elsevier; 2017:chap 33. A, Gershenson DM, Lentz GM, Valea FA, editors. Germ Cell Tumors, Philadelphia: Comprehensive Gynecology Lobo 2017;733-80.

16. Sola R, Wormer BA, Walters AL, Heniford BT, Schulman AM. National trends in the surgical treatment of ovarian torsion in children: an analysis of 2041 pediatric patients utilizing the Nationwide Inpatient Sample. Am Surg 2015;81:844-8.

17. Lipsett SC, Haines L, Monuteaux MC, Hayes K, Michelson KA. Variation in Oophorectomy Rates for Children with Ovarian Torsion across US Children's Hospitals. J Pediatr 2021;231:269-72.
18. Oltmann SC, Fischer A, Barber R, Huanh R, Hicks B, Garcia $\mathrm{N}$. Pediatric ovarian malignancy presenting as ovarian torsion: incidence and relevance. J Pediatr Surg 2010;45:135-9.

19. Virgone C, Alaggio R, Dall'Igna P, Buffa P, Tonegatti L, Ferrari A, et al. Epithelial Tumors of the Ovary in Children and Teenagers: A Prospective Study from the Italian TREP Project. J Pediatr Adolesc Gynecol 2015;28:441-6.

20. Childress KJ, Patil NM, Muscal JA, Dietrich JE, Venkatramani R. Borderline Ovarian Tumor in the Pediatric and Adolescent Population: A Case Series and Literature Review. J Pediatr Adolesc Gynecol 2018;31:48-54.

21. Baert T, Storme N, Van Nieuwenhuysen E, Uyttebroeck A, Damme $\mathrm{N}$, Vergote I, et al. Ovarian cancer in children and adolescents: A rare disease that needs more attention. Maturitas 2016;88:3-8.

22. F Tomao, F Peccatori, L Del Pup, Franchi D, Zanagnolo V, Panici $\mathrm{PB}$, et al. Special issues in fertility preservation for gynecologic malignancies. Crit Rev Oncol Hematol 2016; 97: 206-19.

23. Roett MA. Ovarian cancer. In: Rakel D, Kellerman RD editors. Philedalphia: Conn's Current Therapy 2020; 2019 ;1166-9.

24. Fotopoulou C, Braicu I, Sehouli J. Fertility-Sparing Surgery in Early Epithelial Ovarian Cancer: A Viable Option? Obstet Gynecol Int 2012;2012:238061. 